\title{
How to Measure Sports Brand Equity: A Proposal for Football Industry
}

\author{
João Pedro de Lucena, Joaquim António Casaca \\ IADE-U Instituto de Arte, Design e Empresa Universitário, Lisbon, Portugal
}

\begin{abstract}
As in many other industries, strong brands play an important role in football industry inducing sales for the clubs that own it. Brands financial values are not quantified in balance sheets, so quantifying them provides important financial data. This is the research topic. The research questions are: (i) How is the importance of the brand in the revenues of football clubs and (ii) what is the financial value of the brands Futebol Clube do Porto (FCP), Sport Lisboa e Benfica (SLB), and e Sporting Clube de Portugal (SCP)? This investigation was based on an adaptation of the inter brand equity model. This model considers equity as the economic value generated as net profit of the company, which can be apportioned to the brand. The data was collected from the financial maps of these three clubs between 2005/2006 and 2009/2010 seasons. In order to adapt the model to the football industry, a panel of five experts of professional football club managers was questioned. These experts claim that in football industry, brand management contributes with $16 \%$ of the economic value, sport management with $63 \%$, financial management with $16 \%$, and other factors with $5 \%$. The conclusion is that FCP has the most valuable brand, with about $54.5 \mathrm{~m} €$, followed by SLB with about $51.6 \mathrm{~m} €$, and finally by SCP with about $39.5 \mathrm{~m} €$.
\end{abstract}

Keywords: brand equity, brand management, economic value added

\section{Introduction}

Team sports in general and football in particular are activities that can be considered as services and therefore they are intangible, can be experienced in a short period of time, and induce rather subjective feelings and judgments to its "costumers" (fans); due to their competitive nature, they yield unpredictable results. Nevertheless, team sports cause a much stronger response by their fans than any other activities, except cinema and music (Underwood, Bond, \& Baer, 2001). Similarly to other industries, building up a strong brand capital for team sports can increase fan loyalty, which brings about additional revenue through the sale of other goods and services associated with the team, inside or outside the arena (Burton \& Howard, 1999; Gustafson, 2001). Consequently, the sale of merchandising increases the emotional relationship between fans and the team, since those products act as symbols, identifying the fan, before the team in the arena, as someone who belongs to that tribe as Holt (2002) and Chauduri and Holbrook (2001) investigated. But strong football brand equity also

João Pedro de Lucena, Ph.D., professor of Marketing, IADE-U Instituto de Arte, Design e Empresa Universitário, Lisbon, Portugal.

Joaquim António Casaca, Ph.D., professor, Marketing Department, IADE-U Instituto de Arte, Design e Empresa Universitário, Lisbon, Portugal.

Correspondence concerning this article should be addressed to João Pedro de Lucena, Av. D. Carlos I, 4-1200-249, Lisbon, Portugal. E-mail: joaopedrolucena@sapo.pt. 
impacts the increase in the sponsors' revenues as Richelieu and Pons (2006) demonstrated. Club and players' image rights, the distribution of internet, mobile phone services, the sale of the club's sports apparel, and the development of franchising agreements for official stores are also areas that benefit from a strong brand (Callejo \& Martinez, 2006).

In light of the above, it is important to know: (i) How is the importance of the brand in the revenues of football clubs and (ii) what is the financial value of the brands of Futebol Clube do Porto (FCP), Sport Lisboa e Benfica (SLB), and e Sporting Clube de Portugal (SCP)?

To answer these questions, this article briefly summarizes the relevant literature for this subject, namely regarding brand equity and the models adopted to measure it, with special emphasis on the inter brand model. Subsequently, the method used to calculate the brand value for the three football clubs will be described and then the conclusions and limitations of the investigation will be presented, as well as recommendations for future development within the scope of brand valuation for football clubs.

\section{Literature Review}

\section{Concept and Purpose of the Brand}

In 1960, the American Marketing Association (AMA) defined branding as "a name, term, design, symbol, or a combination of them, intended to identify the goods or services of one seller or group of sellers and to differentiate them from competitors". This core definition reveals the two main purposes of a brand. One that has to do with "identifying" goods or services, i.e., an identity dimension; and the other one has to do with "differentiating" those goods and services, i.e., an imagery dimension.

A brand has an internal dimension as a representation of its identity and an external dimension as an image captured by clients and consumers. It can also be said that identity is the way the brand wants to be perceived and the image is the way the brand is, in fact, perceived. "Image is a reception concept (...) identity is an emission concept" (Kapferer, 1994, p. 33). According to Kapferer (1994), branding identity can be presented as a six face prism. A brand is (1) a "physique" element that can be seen in the visual universe of the brand; (2) a "personality", because it has a nature that can be identified by answering the question "if it was a person, what type of person would it be?"; (3) an element of the "cultural universe", through its association with the values it stands for within the cultural context in which the brand develops and the new behaviors it bring about in a society; (4) a "relationship scenery" between consumers (sensuality, luxury, pretentiousness, love, and etc.). Brand is a "reflection" of the person using the product, i.e., the brand "dresses up" the image of the buyer or user it seems to address. A brand is, finally, a "self-image", because each person builds up a "self" because of its consumption/use. Image, on the other hand, according to Aaker (1991), is a set of associations organized in a relevant way. Keller (1993) stated that image is a set of associations linked to the brand that consumers keep in their memory. These associations, which differentiate the brand and that are valuable for the consumer, justify an increase in the price and can accentuate characteristic that are intrinsic to the product, organization, human features, and/or symbolic and abstract dimensions.

\section{Building a Brand}

A brand affirms its purpose when is able to assure a behavior loyalty. Building and managing a brand are based on the mechanisms activated that induce shopping in a sustained way. Keller (2001) modeled the process of brand building after building block principle that starts from bottom up. The top is called the "resonance" 
block. A brand starts building up at the bottom of the pyramid, i.e., at "Prominence" - the association made by the consumers to a certain type of products or a need. At a second level, the brand must build the "performance" and/or "image" blocks, i.e., offer different aspects valued by the consumer, either regarding the intrinsic performance of the product, or at a symbolic level allowing the product stand out. Once the second level has been achieved, the brand will have within its consumers a set of "judgments" regarding its performance or "sensations" regarding its image that, if consistently assured, it will provide the brand with "resonance" which is the top building block. Chernatony (2001) proposed another model for building a brand which is more suitable for the companies that provide services. This author values the role of management in idealizing and implementing a process based on the understanding and capitalization of the emotional and intellectual dimensions of its employees, as factors to build the external image of the company. It is, therefore, applicable to brand environments populated by people, usually service brands. The brand image is thus formed mainly through the performance of the people providing the service.

Within this context, brand building must start by forming a "long-term vision" that must motivate the employees in order to involve them in its implementation. The "organizational culture", seen as the "artifacts", "values" and "assumptions" (mental models), must align with this brand vision. This vision grants a sense of direction to the brand helping at the same time the process that will allow the brand to establish long-term quantitative "purposes", subdivided into short- and medium-term goals. The "brand environment" encloses the strengths that can increase or prevent the brand image formation. This includes the organization internal environment, distributors, clients, and competitors. These agents are inserted into a macro environmental context (political, social, economic, and technological) that can present opportunities as well as challenges to brand sustainability. The "brand essence" must assertively define the main promise of the brand, ideally translated into a concise statement that reveals the differentiating emotional and functional aspects. In order to implement "brand essence", a "value distribution system" that assures the delivery of the functional aspects produced in the chain of value and the "produced" emotional aspects is required, that is, they should be delivered by the people in the organization. Finally, "brand resources" include the instruments that allow the brand to affirm itself externally and include eight different components: property sign, distinctive name, functional advantages, services, risk reducing mechanisms, legal protection, brand presentation system, and symbolic characteristic.

\section{Brand Equity}

The term "brand equity" came up in the sixties of the last century as a result of the new understanding that the role of the brands was much more than simply identifying products. However, it was only in the eighties of that same century that the term became well known in the USA, as a consequence of the desire both researchers and companies had in understanding the contribution of brands in setting the prices and its contribution for company profits. In 1991, a survey to the researchers of the marketing science institute identified brand equity as the most significant challenge for marketing directors (Aaker \& Biel, 1993). Brand Equity Ten is a model to measure brand equity that is based on the quantification of five dimensions: awareness, perceived quality/leadership measures, loyalty, associations/differentiations, and market behavior. These five dimensions are then divided into ten different metrics, as presented in Table 1.

The nature of model proposed by allows it to adapt to any product and market with the necessary adjustments - "the set of metrics must be adapted to brand specificities" (Aaker, 1996) — and adds that "an 
evaluation of how many metrics need to be included in each dimension must be done. Is it four, eight, or somewhere in between" (Aaker, 1996, p. 336).

Table 1

Brand Equity Ten Model

\begin{tabular}{|l|l|}
\hline \multirow{2}{*}{ Brand Equity Dimensions } & Metrics \\
\hline \multirow{2}{*}{ Perceived quality/leadership measures } & 1. Price premium \\
\cline { 2 - 2 } & 2. Satisfaction \\
\hline \multirow{3}{*}{ Associations/differentiation measures } & 3. Perceived quality \\
\cline { 2 - 2 } & 4. Leadership/popularity \\
\hline \multirow{2}{*}{ Awareness } & 5. Perceived value \\
\hline \multirow{2}{*}{ Market behavior } & 7. Brand personality \\
\cline { 2 - 2 } & 7. Organizational associations \\
\hline
\end{tabular}

Source: Aaker (1996).

Brand equity as an asset with economic value. Brand equity can be comprehended, from the investor's, manufacturer's, or retail seller's point of view (Cobb-Walgren, Ruble, \& Donthu, 2001). Investors are interested in knowing its value as an asset of a company; manufacturers and retail sellers are keener in understanding the strategic implications of brand equity. For manufacturers, a brand allows the increase of their sales volume and margins, while assuring retail sellers a decreased risk when allocating shelf area to that specific brand, thus guaranteeing more consistency in their revenues. However, brand equity for investors, manufacturers, and retail sellers is explained based on the value it has for the consumers. One can, therefore, say that the financial value of a brand is explained by its use value for the consumer.

Keller and Lehmann (2003) developed the brand value chain model that explains the correlation between the value for the client and the value for the investor (shareholder). According to these authors, the brand value is provided to the shareholder via the marketing program, whose quality influences the mindset of the consumer concerning this brand and this circumstance influences the brand performance in the market (amount sold and sale price). Thus, the brand performance in the consumer's mind is a relevant aspect that explains the shareholder's feelings and influences the price per share.

Measuring brand equity. According to Abratt and Bick (2003), the approaches available to value a brand can be divided into four major categories: cost perspective, market perspective, economic perspective, and formulary based approach. The cost perspective values the necessary financial resources needed to establish a brand. It includes research and development of the product's concept, market test, promotion, and improvements to the product. The market perspective has a philosophy based on the price a brand is sold for, being the brand value established according to the revenues it generates. The economic perspective values the net contribution of the brand in creating wealth or in bringing added value to an organization. The formulary based perspective includes the models used by the consulting and marketing companies to value brands, usually in an economic perspective, justifying an autonomous category (Abratt \& Bick, 2003). This paper can include here that the models are, most likely, the ones scholars and consultants use when valuing a brand. 
The inter brand equity model. The inter brand model, created by the consulting company with the same name, sees equity as the economic value generated as net profit of the company which can be apportioned to the brand. It is a perspective focus on the value the brand brings to the business. This model evaluates the brand in three stages: financial analysis, brand role, and brand strength.

Financial analysis. The financial analysis is the projection of the economic results through a methodology similar to the economic value added (EVA). This is not a new model but became more visible, according to Jordan, Veves, and Rodrigues (2007), because the acronym EVA has been registered by company Stern Stewart $\&$ Co.. EVA is calculated according to the information in Table 2.

Table 2

Calculating EVA

\begin{tabular}{|l|l|}
\hline & Operating Profits \\
\hline- & Operating Costs \\
\hline$=$ & Operating Results \\
\hline- & Tax \\
\hline$=$ & Net Operating Profit \\
\hline- & Capital Cost \\
\hline & EVA (Economic Value Added) \\
\hline
\end{tabular}

Basically, this financial performance indicator is calculated by establishing the difference between the return on the capital (net operating profits) and the cost of that capital, either equity or debt's capital (capital cost).

The advocates of this perspective argue that a performance evaluation measure that includes equity costs is more reliable as a way to create value for its owners (Young, 1997), thus differentiating itself from the income measures that only account the interests shown in the financial maps. Hence, a positive EVA means the creation of net value for the shareholders, while a negative EVA means value destruction. The capital cost is obtained with the balance between debt capital (calculated according to interest paid for loans) and the cost of equity (calculated according to the financial assets evaluation model).

Since EVA makes no distinction between the amount the brand contributes with when creating value (Abratt \& Bick, 2003), the inter brand model proposes a process to identify this amount (brand role) in the total of the value generated.

Brand role. The brand role is the part of the economic results of a company that can be apportioned to the brand (Robbin, 2001). The principle, that branded products assure higher profits than the ones without a brand, presupposes that if it is possible to value that profit in "excess" in the future, people will have the actual value of the brand (Aaker, 1991).

Determining the role of a brand can be done with three different methods: primary data, analysis of the historical values of the brand role in the relevant industry and expert evaluation. This last method is one of the most used to identify the percentage the brand represents in the economic profits of football clubs. Its operation is based on the use of a technique called Delphi, whose purpose is for a group of experts in a specific area, participating in the evaluation process anonymously, to reach a consensus on that subject. This technique was developed by an American company, RAND Corporation (from Santa Monica, California) within the scope of an investigation process focused on the military potential of future technologies and respective political consequences (Alvarenga, Carvalho, \& Escária, 2007). 
The Delphi method allows the analysis of qualitative data by finding out the experts' opinions (Delphi panel) through a series of questionnaires. These questionnaires present the participants with a series of specific propositions so that each one of them, individually, orders them according to the established criteria. The results, once aggregated, will be delivered to the experts so they can reformulate the propositions presented. The purpose of this method is to reach a consensus and, for that reason, several rounds will be conducted. However, if the discrepancy is too high in the opinion of a specific expert throughout the different rounds, no consensus will be reached. The opinions may vary from round to round since new questions will be added to each questionnaire and the expert can change its opinion regarding the more relevant questions. This technique has three very important characteristics: anonymity, interaction with controlled feedback, and group statistic replies. Using a panel of experts to obtain knowledge without them being confronted face to face guarantees the anonymity of their answers, besides the use of simple statistic tools to identify patters, which grants consistency to the results. The Delphi method will be used to identify the contribution, in percentage, brands apportion to the economic results of the football clubs.

Brand strength. Brand strength is the projection of the brand value for a five year period, plus the risk value calculated by applying a discount rate that represents the risk of these profits not happening. The inter brand model predicts that the risk rate is associated with seven different factors, each with different percentages: market stability (10\%), brand stability (15\%), leadership (25\%), means of communication (10\%), market share tendency (10\%), internationalization/geographical distribution (25\%), and legal protection (5\%).

\section{Questions of Investigation and Research Methodology}

The questions of investigations are:

(1) How is the importance of the brand in the revenues of football clubs?

(2) What is the financial value of FCP, SLB, and SCP brands?

The research methodology was based on the following elements:

- Use of an inter brand model to value the brands of the three major football clubs (according to Figure 1);

- Analysis of the financial maps of the three public limited sports companies for the 2005-2006 and 2009-2010 seasons;

- Use of a panel of experts to determine the brand role in football clubs, using the Delphi method.

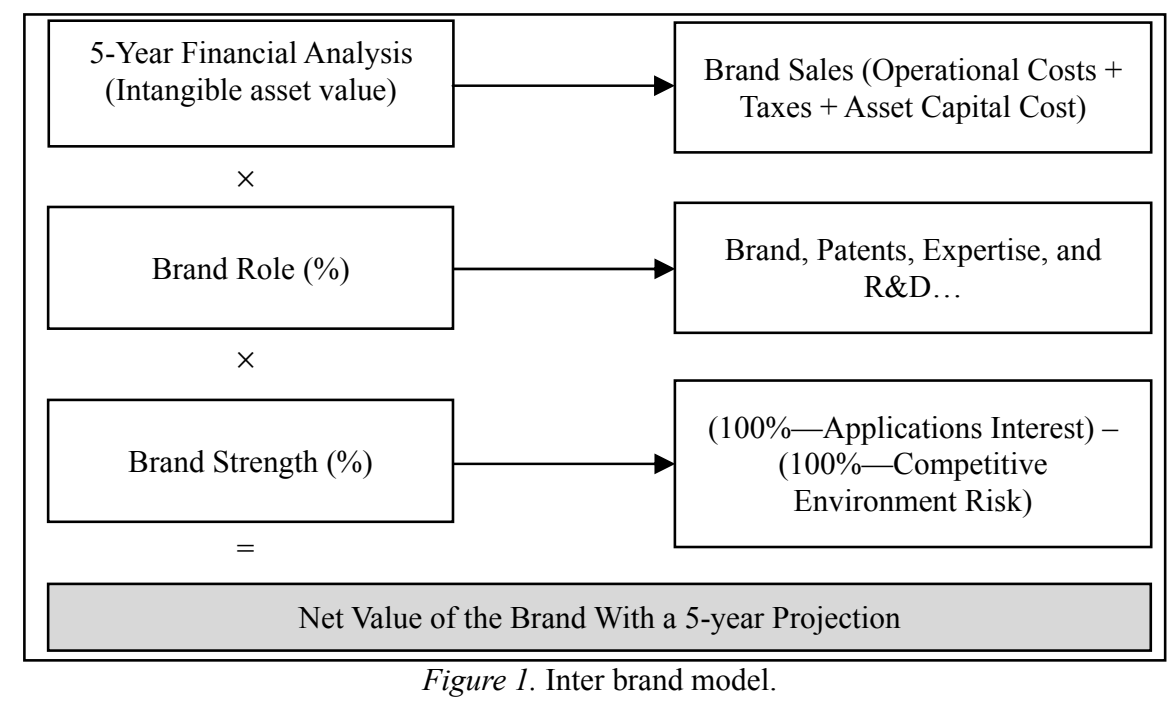

Figure 1. Inter brand model. 


\section{Results and Discussion}

\section{Calculating the EVA}

The first component of the research model adopted has to do with determining the financial performance for each SAD. One of the most frequent measures to calculate that financial performance is called EVA and it is calculated according for formula 1 :

$$
\mathrm{EVA}=\mathrm{OR}-\mathrm{T}-\mathrm{WACC}
$$

where, OR: Operating results (operating revenue - operating costs), including transactions with athletes' registration rights; T: tax (corporate income tax - IRC - plus surtax); WACC: weighted average cost of capital.

The operating results of the three clubs are presented in Table 3.

Table 3

FC Porto, SL Benfica and Sporting CP Operating Results (000€)

\begin{tabular}{llll}
\hline & FCP & SCP & SLB \\
\hline (A) Operating revenue & $56,373.80$ & $41,154.00$ & $52,705.00$ \\
(B) Operating costs & $-59,740.00$ & $-41,620.40$ & $-56,521.00$ \\
$\begin{array}{l}\text { Operating result (1) } \\
\text { (C }=\mathbf{A}-\mathbf{B})\end{array}$ & $\mathbf{- 3 , 3 6 6 . 2 0}$ & $\mathbf{- 4 6 6 . 4 0}$ & $\mathbf{- 3 , 8 1 6 . 0 0}$ \\
(D) Transactions with athletes' registration rights & $5,418.40$ & $-1,189.60$ & 609.20 \\
$\begin{array}{l}\text { Operating result (2) } \\
\text { (E }=\mathbf{C}-\mathbf{D})\end{array}$ & $\mathbf{2 , 0 5 2 . 2 0}$ & $\mathbf{- 1 , 6 5 6 . 0 0}$ & $\mathbf{- 3 , 2 0 6 . 8 0}$ \\
\hline
\end{tabular}

FCP is the only club that has positive operating results, due to the transactions of athletes' registration rights. These operations are usual in these Portuguese clubs, they can be classified as part of their current business.

The weighted average cost of capital (WACC) can be obtained with formula 2:

$$
\mathrm{WACC}=K_{s} \times \frac{\mathrm{EC}}{\mathrm{TC}}+K_{d} \times \frac{\mathrm{DC}}{\mathrm{TC}} \times(1-\mathrm{T})
$$

where $K_{s}$ : cost of equity capital (coefficient); $K_{d}$ : cost of debt capital (coefficient); EC: equity capital; DC: debt capital; TC: total capital (equity + debt); T: tax rate.

In order to calculate the WACC, it is necessary to know the capital structure (equity and debt capital) and respective costs. The equity and debt capital structure and the debt capital cost for each SAD are presented in Table 4.

Table 4

Debt Capital Structure and Cost (000€)

\begin{tabular}{lcccccc}
\hline & \multicolumn{2}{c}{ FCP } & \multicolumn{2}{c}{ SCP } & \multicolumn{2}{c}{ SLB } \\
\cline { 2 - 7 } & $\%$ & Value & $\%$ & Value & $\%$ & Value \\
\hline Debt Capital & $83 \%$ & $78,087.00$ & $117 \%$ & $41,312.40$ & $89 \%$ & $94,785.00$ \\
Equity Capital & $17 \%$ & $16,063.80$ & $-17 \%$ & $-5,990.40$ & $11 \%$ & $11,580.40$ \\
Interest expense & $5.4 \%$ & $4,217.40$ & $5.2 \%$ & $2,165.00$ & $5.9 \%$ & $5,627.00$ \\
\hline
\end{tabular}

The equity capital cost $\left(K_{s}\right)$ is determined through the capital assets price model (CAPM), whose coefficient is calculated with formula 3 :

$$
E_{(r)}=R_{f}+\beta\left[E\left(R_{m}\right)-R_{f}\right]
$$


where $E_{(r)}$ : expected return rate of an asset $\left(K_{s}\right) ; R_{f}$ : return rate of a risk free asset; $\beta$ : risk factor associated with the company; $E\left(R_{m}\right)$ : market expected return rate.

The risk premium (beta) is determined according to the regression of the SAD titles' profitability (dependent variable). Table 5 presents the beta values for each SAD.

Table 5

Regression Models' Coefficients

\begin{tabular}{llll}
\hline & FCP & SCP & SLB \\
\hline Constant $(a)$ & 0.000 & 0.000 & 0.000 \\
Risk factor $(\beta)$ & 0.229 & 0.240 & 0.236 \\
Model adjustment quality $\left(R^{2}\right)$ & 0.009 & 0.009 & 0.011 \\
\hline
\end{tabular}

From the previously identified values and the asset's market return rate (average of the asset's profitability for the seasons being analyzed) and with each beta value shown in Table 5, it is possible to obtain the equity capital cost coefficients for each SAD, according to the data in Table 6.

Table 6

Calculating of the Equity Capital Cost

\begin{tabular}{lccc}
\hline & FCP & SCP & SLB \\
\hline Risk free asset $\left(R_{f}\right)$ & $3.98 \%$ & $3.98 \%$ & $3.98 \%$ \\
Asset's return rate $\left[E\left(R_{m}\right)\right]$ & $-0.03 \%$ & $-0.01 \%$ & $-0.02 \%$ \\
Risk factor associated with the company $(\beta)$ & 0.229 & 0.240 & 0.236 \\
Equity capital cost $\left(E_{(r)}\right)$ & $3.1 \%$ & $3.0 \%$ & $3.0 \%$ \\
\hline
\end{tabular}

Bearing in mind the previously ascertained values and going back to formula 2 , the weighted average cost of capital for each SAD is presented in Table 7. The public limited liability companies FCP, Sporting and Benfica presented a negative EVA as shown in Table 8. These data would determine that the starting question could not be answered by the inter brand model, since all three SAD present a negative economic value.

Before such results, and as mentioned before, authors decided to adjust the model and value the brand based on the market perspective. Instead of evaluating the brand according to the EVA focus, centered in the concept of creation of financial value, this paper evaluated the brand according to the value brought about by revenues, being its indicator the operating profits generated by the brand. Thus, the "brand role" must answer the question "What's the percentage of the profits generated by the brand".

Table 7

Weighted Average Cost of Capital (WACC)

\begin{tabular}{lccc}
\hline & FCP & SCP & SLB \\
\hline Cost of equity capital $\left(K_{s}\right)$ & $3.1 \%$ & $3.0 \%$ & $3.0 \%$ \\
$\%$ Equity Capital $(E C / T C)$ & $17.1 \%$ & $-17 \%$ & $10.9 \%$ \\
Cost of debt capital $\left(K_{d}\right)$ & $5.4 \%$ & $5.2 \%$ & $5.9 \%$ \\
$\%$ Debt capital $(D C / T C)$ & $82.9 \%$ & $117 \%$ & $89.1 \%$ \\
Tax $(1-t)$ & $73.1 \%$ & $73.1 \%$ & $73.1 \%$ \\
Weighted average cost of capital & $3.8 \%$ & $4.0 \%$ & $4.2 \%$ \\
\hline
\end{tabular}


Table 8

Calculating the EVA (000€)

\begin{tabular}{|c|c|c|c|}
\hline & FCP & SCP & SLB \\
\hline (A) Operating Profit & $56,373.80$ & $41,154.00$ & $52,705.00$ \\
\hline (B) Operating costs & $-59,740.00$ & $-41,620.40$ & $-56,521.00$ \\
\hline $\begin{array}{l}\text { Operating result (1) } \\
(\mathbf{C}=\mathbf{A}-\mathbf{B})\end{array}$ & $-3,366.20$ & -466.40 & $-3,816.00$ \\
\hline (D) Transactions with athletes' registration rights & $5,418.40$ & $-1,189.60$ & 609.20 \\
\hline $\begin{array}{l}\text { Operating result (2) } \\
(E=C-D)\end{array}$ & $2,052.20$ & $-1,656.00$ & $-3,206.80$ \\
\hline (F) $\operatorname{Tax}(26.9 \%)$ & 552.04 & & \\
\hline $\begin{array}{l}\text { Net operating result } \\
(G=E-F)\end{array}$ & $1,500.16$ & $-1,656.00$ & $-3,206.80$ \\
\hline (H) Capital cost & $3,574.75$ & $1,401.56$ & $4,464.92$ \\
\hline $\begin{array}{l}\text { EVA } \\
(\mathbf{I}=\mathbf{G}-\mathbf{H})\end{array}$ & $-2,074.59$ & $-3,057.56$ & $-7,671.72$ \\
\hline
\end{tabular}

\section{Calculating the Brand Role}

The second step in this model is to understand the percentage of the operating costs apportioned to the brand. The opinion of experts was gathered through the Delphi technique. A panel of five top professional football managers in Portugal was established, and they were personally contacted to provide their input. The questionnaires were replied by email and the question posed was the following: "In your opinion, which two to seven factors have more impact in the operating results of the football SAD's in the European premier leagues?" The data gathered in these questionnaires revealed three factor axes (dimensions) that explain the operational factors of the football SAD's in the European premier leagues, i.e.: financial and administrative management, brand management, sport management. This data prompted a new consult to the panel with the following question: What percentage would you attribute to the impact of the following factors on the operating results of the SAD's of the Europeans premier leagues?

- Financial and administrative management ability;

- Brand management ability;

- Sport management ability;

- Others.

The results to this questionnaire are shown in Table 9.

Table 9

Calculating Brand Role

\begin{tabular}{lcccccc}
\hline & Prof. 1 & Prof. 2 & Prof. 3 & Prof. 4 & Prof. 5 & Average \\
\hline Financial/administrative & $15 \%$ & $20 \%$ & $20 \%$ & $5 \%$ & $20 \%$ & $16 \%$ \\
Management & $10 \%$ & $10 \%$ & $25 \%$ & $15 \%$ & $20 \%$ & $16 \%$ \\
Brand Management & $75 \%$ & $60 \%$ & $50 \%$ & $80 \%$ & $50 \%$ & $63 \%$ \\
Sport management & $0 \%$ & $10 \%$ & $5 \%$ & $0 \%$ & $10 \%$ & $5 \%$ \\
Others & & & & & \\
\hline
\end{tabular}

These data show that brand management is perceived by the professional football industry in the major clubs as an intangible that is not expressed in the clubs fair assets' value, and that its contribution is of $16 \%$ of the economic value generated by this activity. Applying the $16 \%$ apportioned to "brand role" regarding the operating profits, the results are the ones shown in Table 10. 
Table 10

Calculating the Value of Brand Role (000€)

\begin{tabular}{lccc}
\hline & FCP & SCP & SLB \\
\hline Operating profits & $56,373.80$ & $41,154.00$ & $52,705.00$ \\
Brand Role $\%$ & $16 \%$ & $16 \%$ & $16 \%$ \\
Brand Role $10^{3} €$ & $9,019.80$ & $6,584.54$ & $8,432.80$ \\
\hline
\end{tabular}

\section{Calculating the Brand Role}

How much is the brand worth today in relation to next five years? This question can be answered by multiplying the value of the brand role by six and by seven indexes that quantify the risk of those profits not happening, according to formula 4 :

$$
\mathrm{BS}=i_{1} \times i_{2} \times i_{3} \times i_{4} \times i_{5} \times i_{6} \times i_{7}
$$

where BS: brand strength; $i_{1}$ : market stability $(10 \%) ; i_{2}$ : brand stability $(15 \%) ; i_{3}$ : leadership $(25 \%) ; i_{4}$ : communication support (10); $i_{5}$ : market share tendency $(10 \%) ; i_{6}$ : internationalization/geographical distribution (25\%); $i_{7}$ : legal protection $(5 \%)$.

This popular saying - One can change wives, but not clubs - reveals an accepted paradigm that once someone has become affiliated with a football club, they will never change it throughout their lives, and therefore no changes are foreseen for the three clubs that imply an increase or decrease of the risk associated with brand strength. Within this context, brand strength will be quantified as 1 . The brand value is provided by formula 5:

$$
\mathrm{BV}=\mathrm{BR} \times N \times \mathrm{BS}
$$

where BV: brand value; BR: brand role; $N$ : number of years; BS: brand strength.

The brand value for each of the three clubs is shown in Table 11.

Table 11

Calculating Brand Value (000€)

\begin{tabular}{llll}
\hline & FCP & SCP & SLB \\
\hline Brand Strength & 1 & 1 & 1 \\
Number of years & 6 & 6 & 6 \\
Brand Role $10^{3} €$ & $9,019.80$ & $6,584.64$ & $8,432.80$ \\
Brand Value & $54,658.80$ & $39,507.84$ & $50,596.80$ \\
\hline
\end{tabular}

FCP is the most valuable brand with about 55 M€, followed by SLB with about 51M€, and finally SCP with about $40 \mathrm{M} €$.

\section{Conclusions}

This research found that the brands in football industry are responsible for $16 \%$ of economic value formation, sport management for $63 \%$, and financial management for $16 \%$, while other factors contribute for about $5 \%$. The $16 \%$ apportioned to brand role in the revenues of the three major Portuguese clubs is only an estimation that can change considerably. Larger or more notorious clubs might have a higher contribution than the smaller ones.

This research concluded that FCP presents a more valuable brand equity, with about 54.5 million euros, followed by Benfica with about 51.5 million euros, and finally by Sporting with about 39.5 million euros. The 
study also reveals that SLB, SCP, and FCP present negative economic results, i.e., they destroy value. For the seasons studied, from 2005 to 2010, SLB destroyed, per year, about 7.7 million euros, SCP about 3.1 million euros, and FCP about 2.1 million euros.

The following questions remain unanswered though: Does the $16 \%$ contribution apply equally for each club studied?

Is there any correlation between the size of the club in terms of fans and the contribution of the brand to its operating profits? Another unanswered question is how to value brands in companies that present negative economic results (negative EVA) from an economic perspective and not a market perspective.

The first work hypothesis is that brands have their own goodwill value that allows for a favorable climate with its stakeholders-fans, partners, investors, banks, government, and community in general. A model that can financially value this goodwill as a form of "estimated future income" could be the answer. This goodwill value will be added to EVA. For the cases, when there is a negative EVA, the goodwill value can contribute for a positive economic value and, on the contrary, increase even more the economic value.

\section{References}

Aaker, D. A. (1991). Managing brand value: Capitalization on the value of a brand name. New York: The Free Press.

Aaker, D. A. (1996). Building strong brands. New York: The Free Press.

Aaker, D. A., \& Biel, L. A. (1993). Brand equity and advertising: An overview. Hillsdails: Laurence Erlbaum Associates.

Abrattt, R., \& Bick, G. (2003). Valuing brands and brand equity. The Journal of Applied Managment and Entrepeneurship, 8(1), 21-39.

Alvarenga, A, Carvalho, P. S., \& Escária, S. C. (2007). Delphi: Método e Aplicações (Departamento de Prospectiva e Planeamento e Relações Internacionais, Ministério do Ambiente, do Ordenamento do Território e do Desenvolvimento Regional).

Burton, R., \& Howard, D. (1999). Professionals sports leagues: Marketing-Mix mayehm. Journal of Marketing Management, $8(1), 36-46$.

Callejo, M. B., \& Martinez, F. J. (2006). El real Madrid Club de Fútbol: la Aplicación de un Modelo empresarial a una Entidad Deportiva en España. Universia Business Review-Actualidad Economica, 11, 36-61.

Chauduri, A., \& Holbrook, M. B. (2001). The chain of effects from brand trust and brand effect to brand performance: The role of brand loyalty. Journal of Marketing, 65(2), 81-93.

Chernatony, L. (2001). A model for strategically building brands. Journal of Brand Management, 9(1), 32-44.

Cobb-Walgren, C. J., Ruble, C. A., \& Donthu, N. (2001). Brand equity, brand preference, and purchase intent. Journal of Advertising, 21(3), 193-215.

Gustafson, R. (2001). Product brands look set to gain new advantage, marketing. London: Haymarket Business Publications Ltd..

Holt, D. B. (2002). Why do brands cause trouble? A dialectical theory of consumer culture and branding. Journal of Consumer Research, 29(1), 70-90.

Jordan, H., Neves, J. C., \& Rodrigues, J. A. (2007). O Controlo de Gestão, Ao Serviço da Estratégia e dos Gestores. Lisboa: Areas Editora.

Kapferer, J. (1994). Marcas—Capital da Empresa. Lisboa: Edições Cetop.

Keller, K. L. (1993). Conceptualizing, measuring and managing customer-based brand equity. Journal of Marketing, 57, 1-22.

Keller, K. L. (2001). Building customer-based brand equity. Marketing Management, 10(2), 15-19.

Keller, K. L., \& Lehmann, D. R. (2003). Value emerges through a unique chain of events. Marketing Management, 12(3), 26-31.

Richelieu, A., \& Pons, F. (2006). Toronto Maple Leafs v.s. Football Club Barcelona: How two legendary sports teams built their brand equity? International Journal of Sports Marketing \& Sponsorship, 7, 231-250.

Robbin, A. C. (2001). The potential value of brand accounting (Relatório de Pesquisa de MBA não publicado, Universidade de Witwatersrand, Joanesburgo).

Underwood, R., Bond, E., \& Baer, R. (2001). Building service brands via social identity: Lessons from the sports marketplace. Journal of Marketing Theory \& Pratice, 9(1), 1-13.

Young, D. (1997). Economic value added: A primer for European managers. European Management Journal, 15(4), 335-343. 